IN3 Working Paper Series

INTERNET INTERDISCIPLINARY INSTITUTE

ISSN 2013-8644

\title{
Exploring the use of mobile communications in a retirement home in Toronto
}

Preliminary results

Mireia Fernández-Ardèvol (mfernandezar@uoc.edu)

IN3 - Open University of Catalonia

Working Paper

Working Paper Series WP12-006

Research program: Mobile Communication, Economy and Society

Research program coordinator: M. Fernández-Ardèvol and M. Castells (IN3-UOC)

Submitted in: December, 2012

Accepted in: May 2013

Published in: May 2013
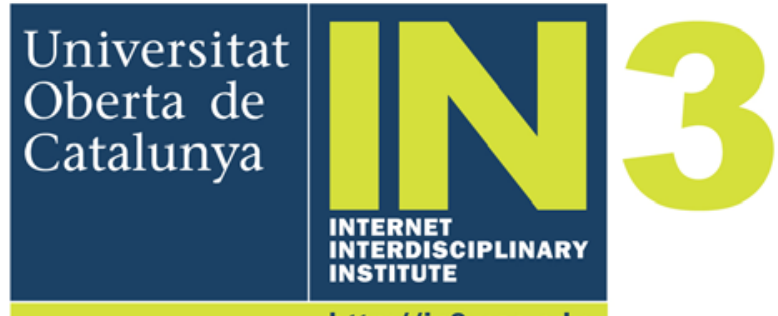


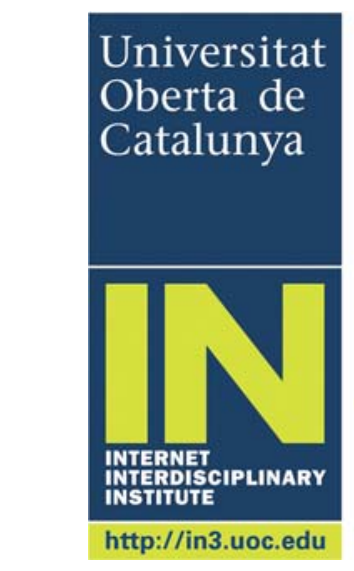

Internet Interdisciplinary Institute (IN3)

http://www.in3.uoc.edu

Edifici MediaTIC

c/ Roc Boronat, 117

08018 Barcelona

Espanya

Tel. 934505200

Universitat Oberta de Catalunya (UOC)

http://www.uoc.edu/

Av. Tibidabo, 39-43

08035 Barcelona

Espanya

Tel. 932532300

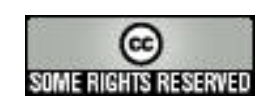

The texts published in this publication are - unless indicated otherwise - covered by the Creative Commons Spain Attribution-Non commercial-No derivative works 3.0 licence. You may copy, distribute, transmit and broadcast provided that you attribute it (authorship, publication name, publisher) in the manner specified by the author(s) or licensor(s).

The full text of the licence can be consulted here:

http://creativecommons.org/licenses/by-nc-nd/3.0/es/deed.en. 


\section{Table of contents}

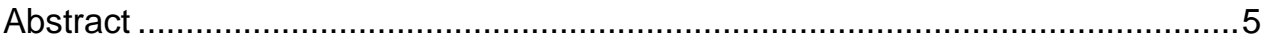

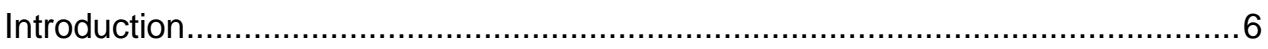

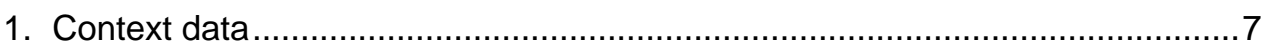

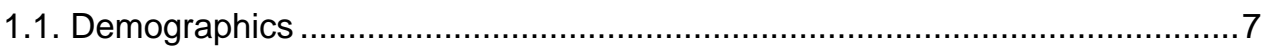

1.2. Information and Communication Technologies...................................... 8

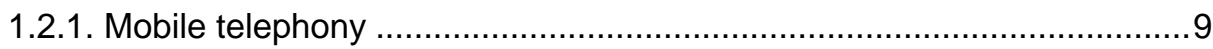

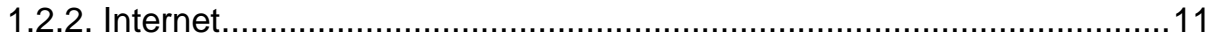

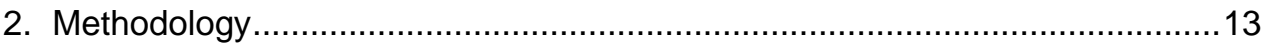

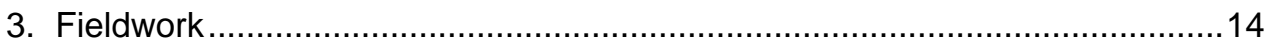

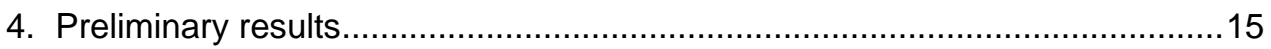

4.1. Sample characteristics .................................................................... 15

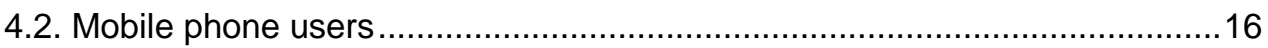

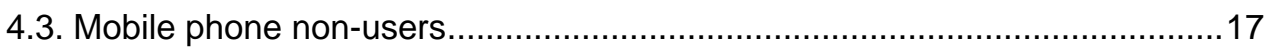

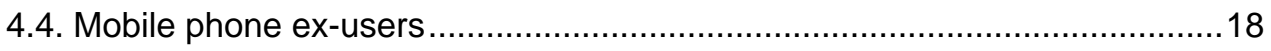

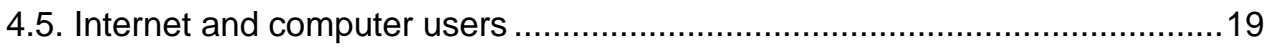

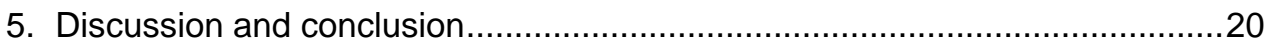

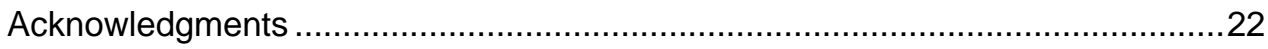

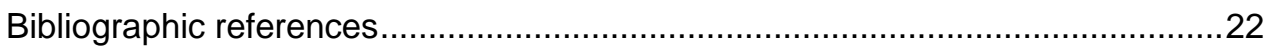

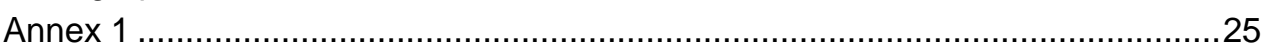

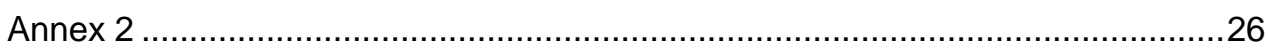




\section{Exploring the use of mobile communications in a retirement home in Toronto Preliminary results}

Mireia Fernández-Ardèvol (mfernandezar@uoc.edu) IN3 - Open University of Catalonia

Recommended citation:

FERNÁNDEZ-ARDÈVOL, Mireia (2012). "Exploring the use of mobile communications in a retirement home in Toronto. Preliminary results" [online working paper]. (Working Paper Series; WP12-006). IN3 Working Paper Series. IN3 (UOC). [Accessed: $\mathrm{dd} / \mathrm{mm} / \mathrm{yy}]$.

$<$ http://in3wps.uoc.edu/ojs/index.php/in3-working-paper-series/article/view/n12Fernandez_2/n12-fernandez_2>> 


\begin{abstract}
This paper describes preliminary results of a qualitative case study on mobile communication conducted in an elders' retirement home in Toronto (Ontario, Canada) in May 2012. This is part of an international research project on the relationship between mobile communications and older people.

Secondary data at a Canadian level contextualizes the case study. We focus on demographic characteristics and on adoption and use of information and communication technologies (ICTs) broken by age.

Participants in the study (21 individuals) are between 75 and 98 years of age, therefore we can consider that the gathered evidence refers to the 'old' older. Mobile phone users in the sample describe very specific uses of the mobile phone, while non-users report not facing external pressures for adopting that technology. The main channel for mediated communication is the landline; in consequences mobile phones -when used- constitute an extra layer of communication. Finally, when members of the personal network of the individuals live abroad they are more prone to use Internet and Skype. We are also able to find ex-users of both mobile telephony and computers/internet who stopped using these technologies because they did not find any use for them.
\end{abstract}

\title{
Keywords
}

Older population; mobile telephony; case study; Toronto; retirement home 


\section{Introduction}

Mobile technology is the most popular communication technology in the world. However, as it happens with the rest of information and communication technologies (ICTs), older people show the lowest rates of adoption in all the countries with available data (ITU, 2012).

Being them accepted or rejected, the relationship with mobile phones should be studied by taking into account the personal system of communication channels (PSCC) of every person. PSCC can be defined as the set of media -devices or services, as fixed and mobile telephony, computer, or Internet-; that each person would identify as being part of their everyday life. The concept fits into the framework of the communicative ecologies, which refers to "the context in which communication processes occur" (Foth and Hearn, 2007, p.9). As explained by Tacchi, Slater and Hearn (2003, p.15): "Instead of focusing on individuals ICTs and their 'impacts' (...) [we] will look at the whole structure of communication an information in a people's way of life. (...) Once we have built up this bigger picture it is far easier to understand the impacts and possibilities of a particular medium, and how [mediated] communications fit into the other things that people are doing".

With this approach understanding how mediated communication fits in individual's activities means taking into account the goals of each mediated communication (Ball-Rokeach, 1985) and whether the different ICTs help to reach these goals to each individual.

This analytical approach raises research questions related to the exploration of the ways this age cohort incorporates, or does not incorporate, mobile communication in everyday life: How do older people use their mobiles? Who do they communicate with by mobile and why? Which combination of communication channels can be found? What are the motivations to reject the use of mobile telephony? Which is the position that mobile telephony occupies in the PSCC of the elders?

This paper discusses the preliminary results of a qualitative case study conducted in Toronto (Ontario) in May, 2012. The aim is to contribute on increasing the evidence and research by exploring distinctive characteristics of mobile telephone use among seniors living in a retirement home. In order to contextualize the situation at a Canadian level, secondary data on demographics and on the use of ICTs are included. This is a work-in-progress report so further analysis is needed to have a complete picture of the studied processes.

The text is organized as follows: section 1 puts the case study in context by discussing selected demographic data and ICTs statistics focused on older

6 
generations in Canada. Section 2 describes the methodology while Section 3 describes the fieldwork. Section 5 is devoted to preliminary results whereas Section 6 discusses the obtained results and concludes.

\section{Context data ${ }^{1}$}

\subsection{Demographics}

In 2012, the population of Canada ascends to 34.9 million. Of them, 7.2 million are individuals 60 years old or over, which constitutes the $21 \%$ of the country population (see Table 1). Half of $60+$ belong to the younger cohort, as 60-69 years old constitute the $10.6 \%$ of the total population. The proportion of seniors is higher among women, as it is their life expectancy. In fact, life expectancy at birth is 83 years old for women and 79 years old for men; while life expectancy at age of 60 years in 26 years for women and 22 for men (United Nations, 2011).

Table 1. Distribution of Canadian Population, by age (2012)

\begin{tabular}{rcccccc} 
& \multicolumn{2}{c}{ Both sexes } & \multicolumn{2}{c}{ Males } & \multicolumn{2}{c}{ Females } \\
persons & $\%$ & persons & $\%$ & persons & $\%$ \\
\hline Total pop. & 34.880 .491 & 100,0 & 17.309 .143 & 100,0 & 17.571 .348 & 100,0 \\
Age: $\mathbf{0 - 5 9}$ & 27.630 .669 & 79,2 & 13.977 .302 & 80,8 & 13.653 .367 & 77,7 \\
Age: $60+$ & 7.249 .822 & 20,8 & 3.331 .841 & 19,2 & 3.917 .981 & 22,3 \\
$60-69$ & 3.708 .143 & 10,6 & 1.808 .138 & 10,4 & 1.900 .005 & 10,8 \\
$70-79$ & 2.114 .739 & 6,1 & 982.738 & 5,7 & 1.132 .001 & 6,4 \\
$80-89$ & 1.169 .811 & 3,4 & 467.717 & 2,7 & 702.094 & 4,0 \\
$90-99$ & 247.847 & 0,7 & 71.071 & 0,4 & 176.776 & 1,0 \\
$100+$ & 9.282 & 0,03 & 2.177 & 0,01 & 7.105 & 0,04
\end{tabular}

Source: Statistics Canada. Table 051-0001 - Estimates of population, by age group and sex for July 1, Canada, provinces and territories, annual (persons unless otherwise noted) (http://www5.statcan.gc.ca/cansim/a33?RT=TABLE\&themelD=3433\&spMode=tables\&lang=eng; accessed: December 10, 2012)

Data from the 2011 Census brings a nuanced picture of the living arrangement of seniors. Nearly 5 million seniors are aged 65 and over in Canada in 2011. Among them, 92.1\% lived in private households or dwellings (as part of couples, alone or with others) while $7.9 \%$ lived in collective dwellings, such as residences for senior citizens or health care and related facilities (see Figure 1). Different generations of seniors show different trends in housing. The proportion of people living in collective dwellings

\footnotetext{
${ }^{1}$ This section benefited from Blanche (2012).
} 
increases with age. In this sense, among seniors in the nineties, over half lived in private households $(56.5 \%)$ while the remaining $43.5 \%$ lived in collective dwellings. On the other hand, $34.0 \%$ of aged 100 and over lived in private households while $66.1 \%$ lived in collective dwellings (Statistics Canada, 2012a).

Figure 1. Living arrangements of seniors. Canada, 2012

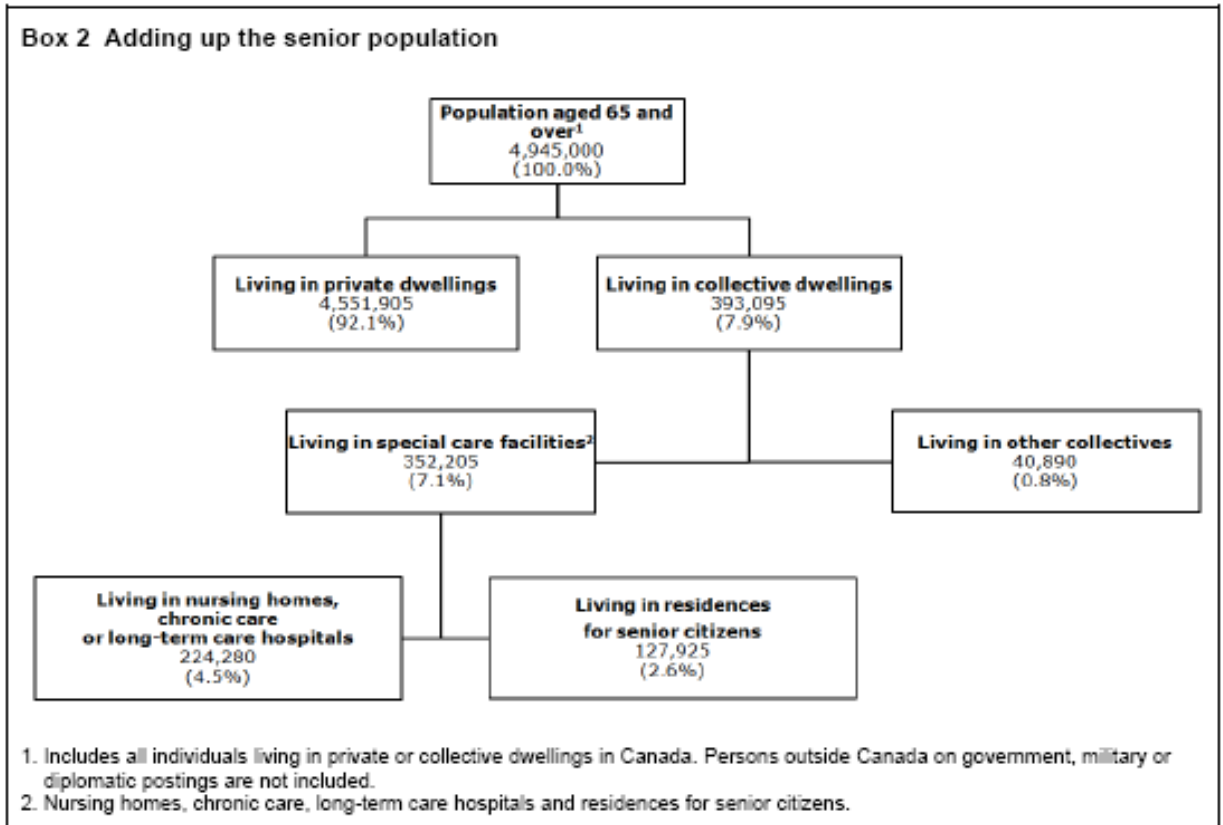

Source: reproduced from Statistics Canada (2012a, page 7).

\subsection{Information and Communication Technologies}

Almost all the Canadian households (99\%) have a mobile phone in 2010 (Table 2). This universal presence is similar to TV sets (99\%), while it surpasses fixed line telephone (90\%), computers (84\%) and Internet connection (79\%). Available data at individual level only bring information on Internet users, who are a majority within the population (80\%). As for the author's knowledge, the available statistic sources do not gather information on adoption of mobile telephony -or computer use- at an individual level.

Up to $96 \%$ of the household with Internet access reported having a high-speed connection. A majority of connected households (54\%) used more than one type of device to go online: $71 \%$ used a desktop computer, $64 \%$ a laptop computer, $35 \%$ a wireless handheld device, and 20\% a games console (Statistics Canada, 2011a). 
In terms of budget, households spent an average of $\$ 1,731$ CAD in 2010 on communications, which represents the $2.45 \%$ of total expenses. This includes an average spending of $\$ 388$ CAD for Internet access $-0.55 \%$ of total household expenses, \$511 CAD for landline telephones and \$731 CAD for mobile phones expenses $-0.72 \%$ and $1.04 \%$, respectively (Statistics Canada, 2012b).

Table 2. ICTs, access and use. Canada (\%)

\begin{tabular}{rr} 
Households with a TV $^{1}$ & 98.9 \\
Households with a fixed line telephone $^{2}$ & 89.3 \\
Households with a mobile telephone $^{2}$ & 99.3 \\
Households with a computer $^{1}$ & 83.9 \\
${ }^{1}$ & 78.9 \\
Households with Internet access at home ${ }^{1}$ & n. a. \\
Mobile cellular telephone users & n. a. \\
Computer users $^{1}$ & Internet users \\
\hline
\end{tabular}

n. a.: data not available. ${ }^{1}$ Year 2010; ${ }^{2}$ Year 2009.

Source: ITU (2012)

\subsubsection{Mobile telephony}

Table 3 gathers industry data on the diffusion of mobile telephony. Mobile penetration in Canada is $75 \%$ in 2011 with 25.86 million active subscriptions, while prepaid subscriptions represent the $17 \%$ of the market.

Table 3. Mobile subscriptions in Canada, 2011

\begin{tabular}{ll}
\hline Mobile penetration $^{1}$ & 75.28 mobile subscriptions per 100 inhabitant \\
Mobile subscriptions $^{2}$ & 25.86 million active subscriptions \\
Of them, prepaid subscriptions $^{3}$ & $17.01 \%$ \\
\hline Source: $^{1 \& 2}$ ITU (2012) and ${ }^{3}$ CWTA (2012).
\end{tabular}

While there are not available data on adoption of mobile telephony, there is profuse information of the characteristics of mobile phone users. Data broken by age confirms a general trend, that is younger people tend to adopt innovations earlier than older people (see Table 4). Therefore, adoption among older age groups is always lower than total population average. First of all, almost half of mobile phone users have a Smartphone in 2012 (48\%), a figure that drops to 24\% among those 55 years old and over. Second, up tot $47 \%$ of mobile phone users have a data plan, a proportion reduced to $29 \%$ among $55+$ individuals. In line with this, going online with the mobile phone is markedly less popular among $55+(11 \%)$ than among the average population (29\%). Tablets are becoming popular among mobile phone users, who mostly use them to connect to a cellular network. Adoption by $55+$ is 5 percent points below the population average. 
Table 4. Ownership of selected technologies, by age. Percentage of mobile phone users. Canada, 2012.

\begin{tabular}{|c|c|c|c|c|c|}
\hline & Total & $18-34$ & $35-44$ & 45-54 & $55+$ \\
\hline \multirow{3}{*}{$\begin{array}{r}\text { Regular mobile phone } \\
\text { Smartphone }\end{array}$} & 52 & 31 & 41 & 56 & 76 \\
\hline & 48 & 69 & 59 & 44 & 24 \\
\hline & 100 & 100 & 100 & 100 & 100 \\
\hline Have data plan in the mobile phone & 47 & 61 & 57 & 47 & 29 \\
\hline Internet browsing with mobile phone ${ }^{1}$ & 29 & 49 & 38 & 20 & 11 \\
\hline Tablet owner & 20 & 23 & 23 & 22 & 15 \\
\hline Tablet connected to a cellular network & 15 & 17 & 16 & 17 & 10 \\
\hline
\end{tabular}

${ }^{1}$ Year 2011

Source: Quorus Consulting Group (2012) for 2012 data, and Source Quorus Consulting Group (2011) for 2011 data.

Information on activities conducted with the mobile phone does not include voice calls. This seems to be a common approach at an international level (among others, Eurostat, 2010 -for the European Union; or Smith, 2010 -for the US) which assumes that voice calls constitute the basic feature every mobile user will have the device for. Table 5 gathers different non-voice activities broken by age. Not surprisingly, the older the age cohort the lower the proportion of individuals declaring doing these activities.

Table 5. Mobile phone activities, by age (18+ population)

Percentage of mobile phone users. Canada, 2011.

(Categories ordered by frequency on $55+$ )

\begin{tabular}{rccccc} 
& Total & $\mathbf{1 8 - 3 4}$ & $\mathbf{3 5 - 4 4}$ & $\mathbf{4 5 - 5 4}$ & $\mathbf{5 5 +}$ \\
\hline Send or receive text messages & 68 & 90 & 79 & 66 & 38 \\
Take pictures & 62 & 81 & 71 & 58 & 37 \\
Send or receive emails & 31 & 44 & 41 & 29 & 17 \\
Use Instant Messaging & 27 & 41 & 35 & 21 & 10 \\
Do online searches & 25 & 41 & 33 & 17 & 10 \\
Pccess maps/navigation instructions & 22 & 34 & 32 & 17 & 10 \\
Capture video & 24 & 38 & 31 & 15 & 8 \\
Cisten to music uploaded to phone & 24 & 44 & 31 & 14 & 7 \\
Do social networking or blogging & 20 & 40 & 26 & 12 & 7 \\
Watch live TV or videos online & 10 & 18 & 13 & 9 & 4 \\
\hline None of the above & 22 & 4 & 11 & 23 & 46 \\
\hline
\end{tabular}

Source: Quorus Consulting Group (2011)

Almost half of the 55+ individuals (46\%) do not conduct any of the non-voice activities they were asked about. Therefore, we can infer that voice calls are the most important service for this age group. Among non-voice services, text messaging is the most popular one: $38 \%$ among $55+$, but far below the $90 \%$ of the 18-34 years old. Taking pictures, an offline activity, stays second in the ranking for all ages $-37 \%$ among 55+ in front of 81 of 18-34 age group; while communicating through e-mails ranks the third $-17 \%$ among $55+$, and $44 \%$ among $18-34$ years old. 
While it becomes obvious that seniors follow a differentiated path of mobile use, it would be of most interest to have more detailed information of the wide group of individuals who are 55 years old and over.

\subsubsection{Internet}

In 2010, 80\% of individuals aged 16 years and older used the Internet for personal use -that is, business uses are not considered. Among them, $33 \%$ went online with a wireless handheld device (Statistics Canada, 2011b). Age differences in access to the Internet are gathered in Table 6: the likelihood of Internet use decreases with age and, what is most, the only age cohort with less than half of the population going online corresponds to those 75 years old and over.

Table 6. Internet users, by age (16 years old and over). Canada 2010.

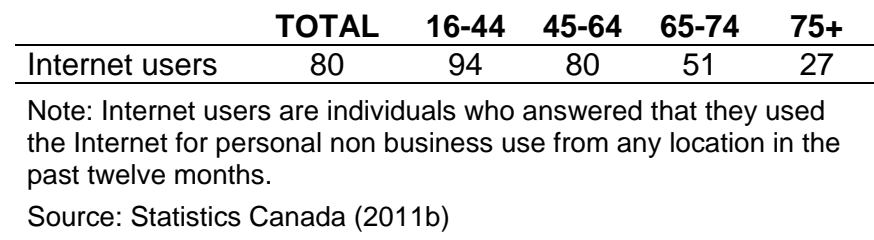

Not only adoption is higher among younger generations but frequency of use is(see Table 7). The most common profile of Internet user corresponds to individuals who go online in a daily base $-67.5 \%$ of $65+$, and $83.9 \%$ of $16-24$ years old group. Seniors do not use Internet as often as other generations but, in general, it seems a regular activity for them as 9 out of 10 goes online at least once a week.

Table 7. Frequency of Internet use, by age. Canada 2010.

Percentage of Internet users (16 years old and over).

\begin{tabular}{lccccc} 
& TOTAL & $\mathbf{1 6 - 2 4}$ & $\mathbf{2 5 - 4 4}$ & $\mathbf{4 5 - 6 4}$ & $\mathbf{6 5 +}$ \\
\hline At least once a day & 75.5 & 83.9 & 80.7 & 67.5 & 67.5 \\
At least once a week (but not every day) & 19.4 & 14.2 & 15.8 & 25.3 & 22.7 \\
At least once a month (but not every week) & 3.5 & 1.3 & 2.8 & 4.7 & 6.8 \\
Less than once a month & 1.5 & $\mathrm{~F}$ & 0.7 & 2.5 & 3.1 \\
\hline
\end{tabular}

Note: Internet users are individuals who answered that they used the Internet for personal non business use from any location in the past twelve months. F: Too unreliable to be published

Source: Statistics Canada. Table 358-0155 - Canadian Internet use survey, Internet use, by age group and frequency of use, occasional (percent) (accessed: December 11, 2012)

Among 22 online activities, e-mail ranges first for every age cohort (see Table 8). Almost all Internet users communicate through e-mail (93.5\%), and due to its high popularity, differences among ages are small -from $96.8 \%$ in the $16-24$ years-old age group to $89.7 \%$ among the $65+$. Other activities, however, rank differently by age 
group, something that we can consider a consequence of the different interests individuals have through their life cycle.

Table 8. Internet activities, by age. Canada 2010.

Percentage of Internet users (16 years old and over).

(Categories ordered by frequency on $65+$ )

\begin{tabular}{rccccc}
\hline & TOTAL & $\mathbf{1 6 - 2 4}$ & $\mathbf{2 5 - 4 4}$ & $\mathbf{4 5 - 6 4}$ & $\mathbf{6 5 +}$ \\
\hline E-mail & 93.5 & 96.8 & 95.6 & 90.3 & 89.7 \\
Search for medical or health-related info. & 64.1 & 58.7 & 68.0 & 63.0 & 62.8 \\
Travel information or travel arrangements & 65.1 & 54.2 & 69.3 & 68.0 & 56.5 \\
Read or watch the news & 68.0 & 69.7 & 73.9 & 63.7 & 54.8 \\
Window shop or browse for information on & 74.3 & 76.5 & 82.4 & 69.5 & 51.8 \\
goods or services & 74.3 & 65.7 & 80.1 & 62.0 & 45.2 \\
Electronic banking & 68.3 & 65.7 & 62.5 \\
Visit or interact with government websites & 64.5 & 60.5 & 73.1 & 62.3 & 42.6 \\
Research community events & 53.9 & 50.1 & 61.4 & 51.2 & 38.4 \\
Play online games & 32.8 & 57.9 & 32.3 & 21.3 & 29.8 \\
Research investments & 27.3 & 16.2 & 29.7 & 30.7 & 25.1 \\
Use instant messenger & 47.2 & 73.4 & 52.3 & 33.5 & 24.3 \\
Use social networking sites & 58.1 & 51.1 & 38.5 & 26.7 & 20.5 \\
Obtain or save software (free or paid) & 91.0 & 70.2 & 36.7 & 19.9 \\
Make telephone calls online & 45.6 & 76.9 & 52 & 28.9 & 18.3 \\
Obtain or save music (free or paid downloads & 27.7 & 28.5 & 17.9 & 18.0 \\
Download/watch movies or video clips online & 47.1 & 75.3 & 55.3 & 30.5 & 17.8 \\
Listen to the radio online & 36.6 & 41.7 & 44.9 & 29.4 & 17.4 \\
Download/watch television online & 32.6 & 54.7 & 39.8 & 18.4 & 11.4 \\
Sell goods or services (through auction sites) & 19.3 & 17.4 & 24.2 & 17.2 & 9.8 \\
Formal education, training or school work & 36.7 & 74.3 & 39.2 & 21.4 & 7.7 \\
Contribute content or participate in discussion & 19.2 & 33.1 & 22.5 & 11.2 & 7.0 \\
groups (blogging, message boards, images) & 19.2 & 55.0 & 47.1 & 25.4 & 3.5 \\
Search for employment & 37.3 & 55.0 &
\end{tabular}

Note: Internet users are individuals who answered that they used the Internet for personal non business use from any location in the past twelve months.

${ }^{1}$ Paying bills, viewing statements, funds transfer

Source: Statistics Canada. Table 358-0153 - Canadian Internet use survey, Internet use, by age group and Internet activity, occasional (percent), CANSIM (database).

In this sense, the second most important online activity for the older age group is gathering of medical or health-related information (62.8\%), which ranks $7^{\text {th }}$ among the total population (64.1\%) and $12^{\text {th }}$ among $16-24$ years old age group (58.7\%). The third most important online activity for 65+ individuals is travel information gathering and travel arrangement (56.6\%). This activity, in contrast, rages 15th among the younger generation (54.2\%) and 5th on average (65.1\%). Among the less popular categories for older people we can identify activities that are not common among 65+ individuals, as job searching (3.5\%) and formal education, training or school work (7.7\%) 2.0 activities are not as popular as they are among younger generations. In fact, $7.0 \%$ of seniors contribute with content or participating in discussion groups and $9.8 \%$ sell through auction sites, in front of $19.2 \%$ and $19.3 \%$, respectively, of the total population. 
Summing up, older population constitutes a significant demographic group in Canada. It shows particular dynamics, as the increasing importance of collective dwelling with age, an important living arrangement of the 'old' older. An analysis of living arrangements shows that collective dwellings increase their importance among the old older. Regarding ICTs, we can confirm the existence of differentiated patterns of adoption and/or of use among generations. Older generations tend to adopt less ICTs and report a more selective use of their services.

\section{Methodology}

This case study is part of a research project devoted to the study of the relationship between mobile communication and older population -that is, population 60 years old and over- in different countries (Fernández-Ardèvol, 2012 in this WP Series and Fernández-Ardèvol and Arroyo, 2012). The goal of the research is to understand the processes and motivations for using (or not using) mobile telephony among senior individuals.

A qualitative approach to the object of study was defined. A flexible, interactive research design is taken to incorporate the specific circumstances in which the research is carried out (Maxwell, 2005:7). The common methodological framework allows further comparison of results among case studies which up to now have been conducted in Barcelona (Catalonia, Spain), Los Angeles (CA, US) and Montevideo (Uruguay).

The case study is mainly based in semi-structured interviews that are complemented by three other techniques of information gathering: a short questionnaire, the observation of the mobile telephone -whenever possible and relevant-; and the notes that are taken after each interview. First of all, every semistructured interview follows a flexible outline and is guided as a relaxed conversation. No correct or wrong answers are expected. Interviews are voice recorded for verbatim transcription and further text analysis. Secondly, the short questionnaire is administered at the end of the conversation (see Annex 1). It is focused on individual socioeconomic characteristics and is adapted to the context of Toronto. Thirdly, handset observation, when pertinent, is allowed by asking permission to take a picture of the device (see selected pictures in Annex 2). This facilitates the observation of how the interviewee handles the cell phone. Finally, notes are taken after the interview. The goal of these notes is to incorporate non oral information of the whole interaction, relevant pieces of information raised when the voice recorder was off and, in general, researcher reflections before, during and after the interview. 


\section{Fieldwork}

The fieldwork was conducted in May $27^{\text {th }}$ and $28^{\text {th }}, 2012$ as an activity of the international network A-C-M (Ageing, Communication, Media). The five researchers of the network plus one research assistant were directly involved in the fieldwork. Language of the interviews was English, except in one case in which the converstion was held in Spanish. ${ }^{2}$

Sample size was targeted to be between 15 and 20 individuals. Mobile ownership was not defined as a selection criterion. This should bring relevant information for a better understanding of the processes of rejection and acceptance of that technology and the relationship of the elderly person with mobile telephony. Furthermore, special attention should be given to the different devices that are in the PSCC of each individual to gain a better understanding of the specific role of mobile telephony.

The final sample gathers information from 21 individuals. ${ }^{3}$ Interviews were carried out in a private and expensive residential home located in a high-income neighborhood of Toronto (Ontario). ${ }^{4}$ Interviews were carried in meeting rooms in the residence, in the garden or in the room/apartment of participants. A reward was delivered at the end of the conversation $-\$ 10$ or $\$ 20 \mathrm{CAD}$, depending on the length of the conversation.

The retirement home facilitated access to residents and helped in the organization of the fieldwork. The key informant in the residence played a role to engage participants in the interviews. While this allows for a sample beyond the initial goal, some participants did not have precise information about the object of the interview and, therefore, needed some previous clarification.

Our focus remains in the analysis of what is been told during the interviews, which usually is a projection, a narrative of what happens in each individual's life (Kvale, 1996). This, a major issue in social sciences research, becomes even more relevant in this case as some participants showed cognitive problems, like short memory problems (not able to remember where to reach the bathroom in the apartment) or disorientation (regarding where they lived or how much time they have been living in the residence). ${ }^{5}$ However, they were able to articulate a narrative around the use of ICTs and other media, and around different aspects of their life that, for them, constitute their reality.

\footnotetext{
${ }^{2}$ Two participants, a couple who had the interview together, asked for the Spanish speaker member of the team -the author, as having the opportunity of talking in Spanish was a motivation for them.

${ }^{3}$ While the number of participants ascends to 22 , the voice record of one interview was lost. As it was not possible to transcribe it and analyze it the same way as the rest of the interviews, it was discarded.

${ }^{4}$ The name of the residential home is kept anonymous.

${ }^{5}$ In 6 cases we were able to notice short memory problems while in one case we were able to notice disorientation.
} 


\subsection{Sample characteristics}

Table 9 gathers some basic characteristics of the sample. It consists on 17 females and 4 males, with age ranging from 75 to 98 years old. The average age is 89.2 years old while the mean age, that is the age that divides the sample by two, is 90 years old. Most part of the sample, therefore, is beyond life expectancy in Canada (see section 1.1). Educational attainment, finally, is relatively high considering the age of the individuals. $^{6}$

Table 9: Sample characteristics

\begin{tabular}{rc} 
Female & 17 \\
Male & 4 \\
\hline Age range (min. - max) & $75-98$ years old \\
Mean age & 90 years old \\
Average age & 89.2 years old \\
\hline Education & 4 \\
University degree or more & 13 \\
High school graduate & 2 \\
Less than high school graduate & 2 \\
No answer & $\mathbf{2 1}$ \\
Source: own elaboration. &
\end{tabular}

With respect to ICTs use and ownership, the majority of the individuals in the sample are mobile non-users (15). Among them, 3 individuals stopped using the mobile phone. Up to 6 participants say they are using a mobile phone the moment of the interview ( 2 men and 4 women). All the individuals except of one have a private fixed line in the residence's room/apartment (20). Besides, 9 participants use computers the moment of the interview, while 7 of them used the Internet. Four participants, in addition, report they stopped using computers at certain point in their lives.

\section{Preliminary results}

Preliminary results reported here correspond to a first analysis of the transcribed interviews and personal notes. More detailed and in depth analysis will be developed in

\footnotetext{
${ }^{6}$ Educational attainment of $65+$ population in Canada is, in 2011: $38 \%$ without High Scholl diploma; $23 \%$ High School diploma; $25 \%$ College or trade certification; and 15\% University degree (source: Statistics Canada, http://www4.hrsdc.gc.ca/.3ndic.1t.4r@-eng.jsp?iid=29, accessed 10/12/2012).
} 
the future. In what follows I describe relevant discourses of mobile phone users, non users and ex-users, as well as Internet and computer users. To guarantee anonymity no real name is used. Participants in the research are identified by their gender, a correlative number and their age.

\subsection{Mobile phone users}

Among mobile phone users we are not able to find sophisticated uses, or even uses that go beyond voice. That is, the mobile phone is "just to phone (...). It rings and I answer" (Woman08, 84 years old). Voice calls is the only service reported, even though one woman expressed her desire of learning how to text (Woman04, 75). Mobile phone users we talked to usually prefer to use the landline, which is considered the main channel for mediated communication and, particularly, for social visits on the phone.

For Woman14 (83), on the other hand, the mobile phone is "an emergency thing". She used to share it with her husband, who passed away some years ago. She always brings it with her to be available to her children. They will first call to her landline in the residence's apartment and, in case they don't find her there, they will use the mobile phone. To her, it is important to be always reachable:

[...] as I say, it's an emergency phone and when I get a call on it, I know that one of my kids really wants to get a hold of me. [...]

That's why I keep it right with me, because it's somebody that needs to get in touch with me now. (Woman14, 83)

It allows her to leave her apartment and be available, connected, to her significant ones, which is important to her. However, she reports two occasions in which she used the mobile phone in an emergency, when she had a car accident and once her husband had a health problem and they were in the car. These were two relevant moments for her to have a mobile phone.

There are other examples in which connectivity is the main reason for having the mobile phone. One case is Woman04 (75) who uses the mobile phone "very little". She decided to buy a mobile phone when she moved to the residence where she has been living for 10 years. She only uses it when she goes out and "rarely anybody" calls her on that phone. When she is in her room, in the residence, she prefers to use the landline. She explains she "could do without a cell phone" but she prefers to use it to be reachable when she goes out. The other case corresponds to Woman08 (84) who decided to buy the mobile phone so she can be connected to her husband, who is sick and bedridden. She says she bought it for safety reasons, as she drives: "I'm told that if I have a problem with the car I can phone for help". She does not explain any emergency situation in which she needed to use the mobile phone. In contrast, she 
explains she uses the mobile phone "very seldom [...], maybe once a week" mainly to phone her husband. She does not talk to him directly, but with the caregiver, to check that everything is OK.

The last example of users corresponds to a couple who explains that they have mobile phone to "call a taxi in the street" (Man20, 90 years old; and Woman21, 87). The couple shares the device, and the husband takes care of it and carries it. They bought the mobile phone the day after the landline broke at their home, few years ago. They do no give the mobile phone number to too many people, but they could give it when very short-term coordination is necessary and they are not in their apartment at the residence. If they have a social call in the mobile phone they would ask the caller to call to the landline: "I'm not at home, now, you better call me to night" (Woman21, 87).

The wife likes very much the landline and she spends lot of time in social visits by phone. She can even spend up to 90 minutes on the phone. Her husband would remain specific calls she wanted to make but would go out for a walk during these conversations as he does not like the phone very much. These calls can also be international calls, as their personal network, no only relatives but friends, is located in different countries and she enjoys very much keeping in touch with them.

They are not the only ones who share a mobile phone. Besides the example above (Woman14, 83), a man (Man02, 84) reports sharing the device with her wife, who is the one who has the mobile phone at the moment of the interview as she is in a nursing home. He explains that would like to have the mobile phone with him, though.

\subsection{Mobile phone non-users}

Some mobile phone non-users explain that the device does not fit in their way of life, a life style which is different from those active in the labour market or those joining more activities. Various individuals give similar arguments:

"I haven't found any use for it. (...)The lifestyle...I mean, I'm not hopping all over and...if I was going around with....and my wife was alive and something...and you were going downtown, I want to phone her or something, I would have one. But I haven't found any use for it." (Man15, 98)

"I don't think that I would get the value out of it, you know? (...) I mean, if I ever go into business or are involved in things like that you are, where they have to know where I am and want to be able to get hold of me easily, I would probably have a cell phone or that sort of thing, but so far I don't feel the need (...). If I were working, you know." (Woman05, 90)

"I really have no use [for it]. So far I haven't found that I really need it. (...) If I needed one I would get one. (...)But I really haven't found the need for it." (Woman06, 94)

"I just didn't fell I needed it. (...) I can phone from my place." (Woman16, 94) 
Another woman, who has a bad opinion about mobile phones, seems to be more ideologically positioned in the way she explains her decision:

"I've decided I don't need one [cell phone]. (...) And I don't want one. They seem to be getting more and more complicated. They do more things than...one seems to outdate the other. (Woman01, 87)

She also considers that the way she lives does not deserve a mobile phone:

"I'm really not interested. I live here. I don't usually disappear from this place for more than a few hours and my telephone takes messages. (...) at my age there's no reason for them [my children] to have to contact me immediately, and I can always contact them." (Woman01, 87)

Other participants, however, do not give any specific motivation for not having a mobile phone. In any case, all of them have a landline so their mediated communication is assured as all the rooms and apartments in the residence home were prepared for having a landline. ${ }^{7}$

\subsection{Mobile phone ex-users}

Those who stopped using the mobile phone constitute an interesting group, given their motivations. The 3 ex-users in the sample do not miss the mobile phone. In fact, they explain they did not use it very much when they had it.

First case is Woman12 (89). She explains that "at my age I can pick and choose what I want to do and I don't want to do". She had a mobile phone "for a while", "because everybody had one" but she realized she did not need it:

"(...) if I don't need it [mobile phone], I'm not going to have it, I don't want it." (Woman12, 89)

She explains that she is not "a gadget person". She prefers talking to the people in the residence home than focusing of technological devices. She is not now interested in learning how they work as they do not seem useful to her. She supports her decision with arguments related to her own empowerment since she is retired:

"If I need to know it, you know, if there was something in my life that I needed to know, that I needed in my work, I don't have work anymore. Thank goodness! I did enough work in my life and I don't have to work anymore. And I'm not picking up any new stuff to do. (...) I'm not going to spend time learning about gadgets and new things that I'm not going to use [it], I won't have use of them." (Woman12, 89)

Second case is Woman09 (95) who used to have a mobile phone mainly for emergency uses. She bought a device because she though "it was wise" to have it

\footnotetext{
${ }^{7}$ The only exception is a man who moved to the residence recently before the interview and said he had not landline no mobile phone (Man01, 94 years old).
} 
when driving. She already had the mobile phone when she moved to the retirement home, but the device broke and she never replaced it as nowadays she does not really need it:

"Something happened to it [the mobile phone] and since I'm in the retirement home I just haven't bothered to replace it. Sometimes I regret it but it's nothing that's really vital to my way of life (...) because I'm not doing what I used to do. I wasn't out a lot and...I was out a lot, but not now." (Woman09, 95)

Lastly, Woman06 (94) used to have a mobile phone in her car but never used it. She bought her first mobile phone in the first half of the 1990's, when they appeared in the market. She followed her children advice, as she used to drive regularly more than $100 \mathrm{~km}$ distance from Kitchener to Toronto.

She says that, at present, she would have a mobile phone if she needed "but I really haven't found the need for it." In addition, she reports usability issues for not using a mobile phone, plus the concern of not being able to use it:

“The numbers seem to be very small and I don't know whether I can manipulate it properly. (...) Also I don't hear well and a lot of them are too soft (...) and I can't hear properly. (...) So l'd rather not start." (Woman06, 94)

None of these 3 ex-users report having external pressures for having a mobile phone. They, in fact, constitute a subset of non-users that also think that the mobile phone does not fit in their way of life.

\subsection{Internet and computer users}

Playing (offline) games is the most popular activity among computer users in the sample. On the other hand, for those who go online, the email is the most popular service. Participants mostly have their own computer while in some occasions they use the computer located in the residence's library. Internet connection goes, for all of them, through a computer -a desktop or a laptop- as nobody reports using a handheld device to going online.

Three participants who use Skype are particularly interesting to understand how important motivations are for using a technology or a service. First one is Woman09 (95), second one is Woman08 (84) who has got the computer for 5 years, and last one is Woman10 (87) who has been using computers for the last 24 years. For all of them, Skype means communication with their children abroad. The possibility of going beyond voice conversations is highly appreciated.

Woman09 (95) lost her interest for computers. She describes her use of computers as limited "I never learned more than sending an email and I'm not great at that", but the moment her granddaughter and her family moved to Dubai (Arab Emirates) and the telephone became too expensive she regained her interest on Internet, both e-mail and 
Skype. On the other hand, Woman08 (84) reports she uses Skype with one son who lives in the US and with a friend who lives in Europe. She reports usability problems, and explains she just had technical problems before the interview: she was not able to set up a Skype conversation as, due to software updates, something worded different and she was not able to logging in.

While these two participants have a mobile phone, the third one, Woman10 (87), does not, even though she has long experience in using computers. She, in fact, finds the computer more useful than the telephone:

I think the telephone is limited, I think a computer has more accessibility, I have more access to a wider world: I have Skype, I can talk to my children, my grandchildren in Africa, to my friends in Australia, to my family in England, to friends in America. It is worldwide, and through the medium of the computer weekly I get reports from an association of children, of women with children, and we all grew up in a home. And through that I've kept in touch with people I grew up [with], I understand how their lives have evolved and, quite frankly, I don't think I could do without that means of communication. (...) Also I can download what I want. I've got chess on it, I've got Scrabble, I've got word games, so I find the computer is almost like a limb, like part of my body. (Woman10, 87)

By stating that the computer is almost like a limb, she shows a relationship with the connected computer that is closer to what is common in younger generations. In fact, she is the only participant who describes that close relationship with Internet and the computer while, interestingly, she does not have a mobile phone. She manages her global world through the Internet and her local world through the landline and the Internet.

\section{Discussion and conclusion}

The case study, conducted in a retirement home, allows us to learn about the uses of mobile communication and other ICTs within a group of 'old' older individuals -with ages ranging from 75 to 98 years old. For those who are users, the mobile phone is described to be useful for specific goals of communication (Ball-Rokeach, 1985) within a given communicative ecology (Tacchi et al, 2003). All the rooms in the residence are prepared for having a landline and the residence's management fosters newcomers to bring their own devices from home, which this includes the regular phone(s) they had been using. Consequently, their mediated communication can be kept similar as it was 
before moving to the retirement home and the communicative ecology can be maintained to a certain degree. ${ }^{8}$

Participants often identify the mobile phone as a device related to emergencies. We can, therefore, consider it a lifeline (one of the central images of the devices at first stages of adoption -Oksman and Rautiainen, 2002; Ling, 2004: 35). However, the everyday life use of the device is mainly related to connectivity on the go: to be reached and to reach others when out of the residence's room/apartment. At their stage of life, participants explain that connectivity can be important in two senses. First one is to check that others are OK, as for Woman04 who wants to check with her husband. Second one is to report to others, usually the own adult children. This is what Woman14 explains; as if she does not answer the phone her children will be worried. In this sense, ageing would mean becoming a person who is looked after by others usually close relatives. Finally, micro-coordination (as defined by Ling, 2004: 70) is described as one of the main roles of the mobile phone in one case (Man20 and Woman21).

Voice communication is the most important service for participants. The mobile phone is a phone, an idea that is clearly summarized in one sentence: "It rings and I answer" (Woman08). Finally, the mobile phone constitutes an extra layer of communication within the personal system of communication channels (\#reference_deleted_for_blind_review) within the communicative ecology of each individual.

Among non-user, no feelings of external pressures for having a mobile phone are reported. As they do not see any use for this technology they do not make any step towards adopting it. Ageing discourse is used to justify their decision in some cases, but the argument can be built in two different ways. First one is that are too old for these device; while the second one is that at their age they can decide where to put their time and interest in. First discourse is related to weakness while the second one is related to empowerment.

Ex-users follow the same logics. Interestingly, at some point they decided to stop using the mobile phone. They reached this situation through different paths. It might be because the device broke and they did nothing to fix it (which indicates that it was not that important) or because they consciously decided not to use it any more.

Finally, when it is worth enough, going on line is kept as an activity in the agenda of the elders we interview. This is particularly valid for the use of Skype. Those individuals who have members of their personal network living abroad will have greater motivation on using the Internet for communicating with them. This, however, is not always valid. Woman21 is an exception, as she prefers to set international calls that constitute social visits on the landline. All of them have a shared goal, establishing long distance communication, while the channel each individual relays on can be different.

\footnotetext{
${ }^{8}$ One alteration is that the landline number changes.
} 
Summing up, we can confirm that the evidence in this case study, conducted in a wealthy retirement home in Toronto, leads to similar evidences gathered in other places. First of all, within the studied sample, and for those who are mobile users, the mobile phone is seen as a tool that accomplishes a function which is specific and is kept specific. This function is based on voice communication. On the other hand, the mobile phone, as well as the Internet, is incorporated in everyday life practices when it is perceived as a useful tool. Otherwise it is ignored or discarded.

Regarding secondary data available from different sources at a Canadian level, we have been not able to find statistics on adoption of mobile telephony. Available data focus on the profile of mobile users and the services they use -excluding voice communication which seems to be assumed that is part of communication practices of mobile phone owners. In addition, seniors are reported as an homogeneous group that are summarized under the label " $55+$ " or " $65+$ ", depending on the source.

\section{Acknowledgments}

Support of IN3-UOC and of SSHRC Canada for this research is gratefully acknowledged. This case study was conducted within the framework of the international network A-C-M (Ageing, Communication, Media). The author would like to acknowledge all the interviewed individuals. Researchers and research assistants of the A-C-M involved in this case study are: D. Blanche, B. Crow, M. Esseghaier, L. Grenier, K. Sawchuk and C.Y. Wong. Main facilitators were B. Crow and J. Sardella Director of Recreation at the residence home. Paper took profit from discussions within the A-C-M network. The usual disclaimer applies.

\section{Bibliographic references}

Ball-Rokeach, S. J. (1985): The origins of individual media-system dependency: A sociological framework. Communication Research, 12(4), 485-510.

Blanche Tarragó, D. (2012): ICT facts of four countries, First Draft, May, mimeo, 79 p.

Castells, M.; Fernández-Ardèvol, M.; Qiu, J. L.; Sey, A. (2006): Mobile Communication and Society: A Global Perspective. Cambridge, MA: MIT Press.

CWTA (2012): Wireless phone subscribers in Canada Facts \& Figures 2011. Canadian Wireless Telecommunications Association, http://cwta.ca/wordpress/wpcontent/uploads/2011/11/SubscribersStats en 2011 Q4.pdf (01/12/2012) 
Eurostat (2010): Statistics on the Use of Mobile Phohe [isoc_cias_mph], Special module 2008: Individuals - Use of advanced services, last updated 09-08-2010, http://appsso.eurostat.ec.europa.eu/nui/show.do?dataset=isoc cias mph\&lang=en (05/12/2012).

Fernández-Ardèvol, M. (2012): Older population and mobile communication in Los Angeles. Preliminary results of a case study. IN3 Working Paper Series, North America, 0, mar. 2012. Available at: http://in3wps.uoc.edu/ojs/index.php/in3working-paper-series/article/view/n12-fernandez (08/03/2013).

Fernández-Ardèvol, M.; Arroyo, L. (2012): Mobile phone use among elderly people: An exploration of adoption processes, Interactions: Studies in Communication \& Culture, 3(1), 9-24.

Foth, M.; Hearn, G. (2007): Networked individualism of urban residents: Discovering the communicative ecology in inner-city apartment buildings. Information, Communication \& Society, 10(5), 749-772.

ITU (2012): World Telecommunication/ICT Indicators Database 2011, Geneva, Switzerland: International Telecommunication Union.

Kvale, S. (1996): Interviews: An Introduction to Qualitative Research Interviewing, Sage Publications, Thousand Oaks California.

Ling, R. (2004): The Mobile Connection: The Cell Phone's Impact on Society. San Francisco, CA: Morgan Kaufmann.

Maxwell, J. A. (2005): Qualitative research design: an interactive approach, 2nd ed. Thousand Oaks, CA: SAGE Publications.

Oksman, V. and Rautiainen, P. (2002): I've got my whole life in my hand. Revista de Estudios de Juventud, 52: 25-32.

Quorus Consulting Group (2011): 2011 Cell phone consumer attitudes study. n.p.: Canadian Wireless Telecommunications Association. http://www.cwta.ca/CWTASite/english/facts figures downloads/Consumer2011.pdf $(03 / 12 / 2012)$

Quorus Consulting Group (2012): 2012 Cell Phone Consumer Attitudes Study. n.p.: Canadian Wireless Telecommunications Association. http://cwta.ca/wordpress/wpcontent/uploads/2011/08/CWTA-2012ConsumerAttitudes1.pdf (03/12/2012)

Smith, A. (2010): Mobile Access 2010. Pew Internet \& American Life Project, 32 pages. http://pewinternet.org/Reports/2010/Mobile-Access-2010.aspx (27/09/2011).

Statistics Canada (2011a): The Daily, Wednesday, May 25, 2011. Canadian Internet Use Survey, http://www.statcan.gc.ca/daily-quotidien/110525/dq110525b-eng.htm (05/12/2012)

Statistics Canada (2011b): The Daily, Wednesday, October 12, 2011. Individual Internet use and E-commerce, http://www.statcan.gc.ca/dailyquotidien/111012/dq111012a-eng.htm (05/12/2012)

Statistics Canada (2012a): Living arrangements of seniors. Census in Brief 2011 No. 4, $10 \mathrm{p}$, Catalogue no. 98-312-X2011003. http://www12.statcan.gc.ca/censusrecensement/2011/as-sa/98-312-x/98-312-x2011003_4-eng.pdf (05/12/2012) 
Statistics Canada (2012b): Survey of Household Spending, 2010. The Daily, April 25. Component of Statistics Canada catalogue no. 11-001-X Retrieved December 10, 2012 from http://www.statcan.gc.ca/cgi-bin/af-fdr.cgi?teng=dq120425aeng.pdf\&tfra=dq120425a-fra.pdf\&l=eng\&loc=dq120425a-eng.pdf (03/12/2012)

Tacchi, J. A., Slater, D., Hearn, G. N. (2003): Ethnographic action research: A user's handbook. New Delhi, India: UNESCO. Retrieved from http://eprints.qut.edu.au/4399/1/4399.pdf (10/09/2012)

United Nations (2011): The 2010 Revision. , United Nations, Department of Economic and Social Affairs, Population Division (2011), World Population Prospects http://www.un.org/esa/population/unpop.htm (10/12/2012). 


\section{Annex 1}

\section{Questionnaire $^{9}$}
(1) Age
(2) Birth place

(3) When did you move to this retirement home?

(4) Where did you use to live before moving to this retirement home? (No address needed, just the area or the neighborhood)

(5) Educational attainment

$\square$ No chance to go to school
$\square \quad$ Less that $9^{\text {th }}$ grade
$\square \quad 9^{\text {th }}$ to $12^{\text {th }}$ grade (no diploma)
$\square$ High school graduate
$\square$ Some university or college education
$\square$ Bachelor degree
$\square$ Advanced degree (MA, PhD)

(6) Are you retired?

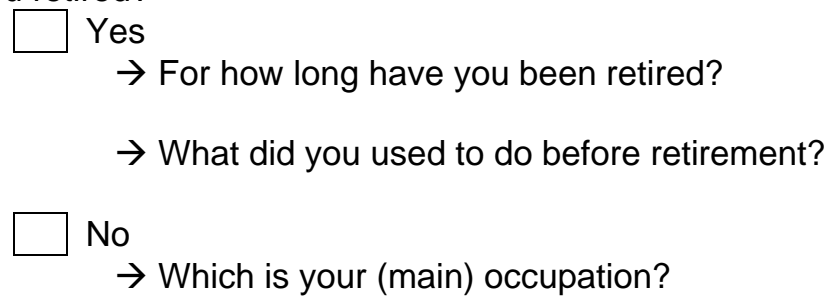

(7) What is your yearly income? (\$CAD)

\begin{tabular}{|c|c|}
\hline$<\$ 9,999$ & $\$ 50,000-\$ 59,999$ \\
\hline$\$ 9,999-\$ 19,999$ & $\$ 60,000-\$ 74,999$ \\
\hline$\$ 20,000-\$ 29,999$ & $\$ 75,000-\$ 99,999$ \\
\hline$\$ 30,000-\$ 39,999$ & $>\$ 100,000$ \\
\hline$\$ 40,000-\$ 49,999$ & \\
\hline
\end{tabular}

\footnotetext{
${ }^{9}$ Participants were informed that they can leave unanswered any question they want to. Flexibility allowed for different ways of delivering the questionnaire. Therefore, even though it was designed to be an oral questionnaire, in one interview the circumstances guided to a written by one of the interviewees.
} 


\section{Annex 2}

Pictures of selected mobile phones

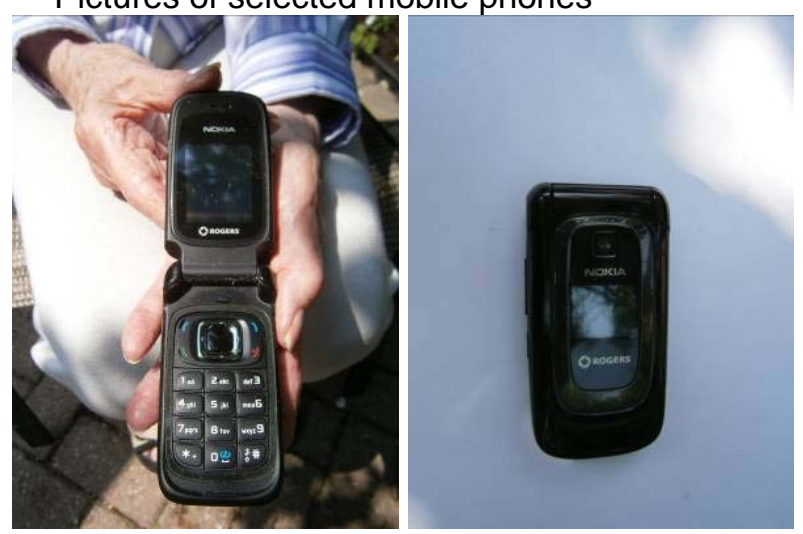

Woman14 (83 years old)

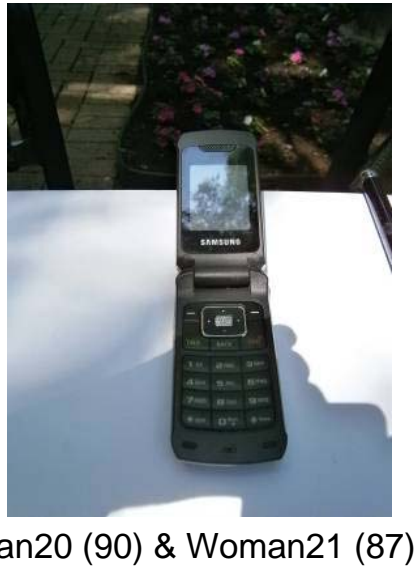

Man20 (90) \& Woman21 (87) 


\section{Resumen}

Como parte de un proyecto de investigación internacional sobre comunicaciones móviles y tercera edad se ha llevado a cabo un estudio de caso cualitativo en una residencia de la tercera edad en Toronto (Ontario, Canadá). En este artículo se presentan los resultados preliminares del estudio, cuyo trabajo de campo se llevó a cabo en Mayo de 2012.

Mediante datos secundarios sobre Canadá contextualizamos el estudio, revisando las características demográficas y los niveles de adopción y uso de las TIC (tecnologías de la información y las comunicaciones) en función de la edad.

Las personas que han participado en el estudio (21) tienen edades comprendidas entre los 75 y los 98 años, por lo que podemos considerar que nuestra evidencia se centra en los mayores 'mayores'. Entre estas personas, las usuarias de teléfono móvil describen unos usos muy específicos del aparato, mientra que quienes no utilizan esta tecnología reportan que no perciben ninguna presión externa para tener un móvil. El principal canal de comunicación mediada es el teléfono fijo, de manera que el móvil, cuando lo utilizan, se constituye como una capa extra de comunicación. En relación a las actividades en línea, cuando algún miembro de la red personal próxima vive en el extranjero, se observa una mayor predisposición a utilizar Internet y Skype. Finalmente, entre las personas que han participado en el estudio hay ex - usuarias, tanto de teléfono móvil como de Internet, que han dejado de utilizar estas tecnologías porque no veían su utilidad.

\section{Palabras clave}

Tercera edad; telefonía móvil; caso de estudio; Toronto; residencia de la tercera edad 


\section{Resum}

Com a part d'un projecte de recerca internacional sobre comunicacions mòbils i gent gran s'ha dut a terme un estudi de cas qualitatiu en una residència de gent gran de Toronoto (Ontario, Canadà). En aquest article es presenten els resultats preliminar de l'estudi, el treball de camp del qual es va dur a terme el mes de Maig de 2012.

Mitjançant dades secundàries sobre Canadà contextualitzem l'estudi, revisant les característiques demogràfiques i els nivells d'adopció i ús de les TIC (tecnologies de la informació i les comunicacions) en funció de l'edat.

Les persones que han participat en l'estudi (21) tenen edats compreses entre els 75 i el 98 anys, per tant podem considerar que la nostra evidència se centra en les persones grans "grans". Entre elles, les usuàries de telèfon mòbil descriuen uns usos molt específics de l'aparell, mentre que les que no el fan servir no descriuen pressions externes per tenir-ne un. El seu principal canal de comunicació mediada és el telèfon fix de manera que el telèfon mòbil, quan el fan servir, constitueix una capa extra de comunicació. En relació a les activitats en línia, quan algun membre de la xarxa personal propera de l'individu viu a l'estranger, s'observa una major predisposició a emprar Internet i Skype. Finalment, entre les persones participants hi ha ex-usuàries tant de telèfon mòbil com d'Internet/ordinador que han deixat de fer servir aquestes tecnologies perquè no li trobaven la utilitat.

\section{Paraules clau}

Gent gran; telefonia mòbil, estudi de cas; Toronto; residència de gent gran 


\section{Mireia Fernández-Ardèvol \\ mfernandezar@uoc.edu \\ Research prgram Mobile Communication, Economy and Society \\ IN3 - Universitat Oberta de Catalunya}

Mireia Fernández-Ardèvol holds a PhD in Economics (University of Barcelona, UB) and a degree in Economics (UB) and in Business Administration (UB). She is the co-director of the

Research Program "Mobile Communication, Economy \& Society" at the Internet Interdisciplinary Institute IN3 (UOC, Open University of Catalonia). Mobile communication has been one of her main areas of study since 2003, , with a combined sociological and economic focus. Her interests are set both in developed and in developing countries. More info: <http://www.femrecerca.cat/mireia>.

\section{Mireia Fernández-Ardèvol \\ mfernandezar@uoc.edu \\ Research prgram Mobile Communication, Economy and Society IN3 - Universitat Oberta de Catalunya}

Mireia Fernández-Ardèvol és Doctora en Economia (Universitat de Barcelona, UB) $i$ Ilicenciada en Economia (UB) i en Administració i Direcció d'Empreses (UB). Codirigeix el

programa de recerca "Mobile Communication, Economy and Society" al Internet Interdisciplinary Institute IN3 (UOC). La comunicació mòbil és una de les seves principals àrees d'estudi des del 2003. Combina la perspectiva sociològica i econòmica, i els seus interessos se centren tant en contextos desenvolupats com en contextos en desenvolupament.

Més informació: <http://www.femrecerca.cat/mireia>

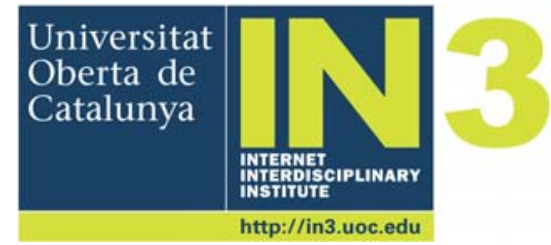

